\title{
PENGEMBANGAN PERANGKAT PEMBELAJARANMATEMATIKA MENGGUNAKAN MODEL TEAM GAMES TOURNAMENT UNTUK MENINGKATKAN KEMAMPUAN PEMECAHAN MASALAH SISWA MTs
}

\author{
Abdul Rasyid Fadhlan Khair ${ }^{1}$, Hamidah Nasution ${ }^{2}$, Asmin $^{2}$
}

\begin{abstract}
ABSTRAK
Pengembangan Perangkat Pembelajaran Matematika Menggunakan Model Teams Games Tournament untuk Meningkatkan Kemampuan Pemecahan Masalah Dan Self-Efficacy Siswa MTs PAB-1 Helvetia. Penelitian ini bertujuan untuk membandingkan peningkatan kemampuan pemecahan masalah siswa MTs PAB-1 Helvetia melalui model team games tournament, mendeskripsikan keefektifan pembelajaran matematika untuk topik bangun datar di kelas VII MTs PAB-1 Helvetia. Penelitian ini merupakan penelitian pengembangan. Populasi penelitian ini adalah siswa MTs PAB-1 Helvetia. Pemilihan sampel dilakukan secara random dengan mengacak kelas. Siswa kelas VII (1) sebagai kelas eksperimen yang diberi perlakuan model team games tournament dan siswa kelas VII (5) sebagai kelas kontrol yang diberi perlakuan pembelajaran biasa. Instrumen yang digunakan terdiri dari: tes kemampuan pemecahan masalah, angket self-efficacy, aktivitas siswa, proses jawaban siswa. Analisis data dilakukan dengan uji t dan anava dua jalur.Hasil utama dari penelitian ini adalah: (1) Peningkatan kemampuan pemecahan masalah matematika yang memperoleh model team games tournament lebih tinggi dibandingkan siswa yang menggunakan pembelajaran biasa, (2) Peningkatan self-efficacy siswa yang memperoleh model team games tournament lebih tinggi dibandingkan siswa yang menggunakan pembelajaran biasa, (3) Terdapat interaksi antara pembelajaran dengan kemampuan awal siswa terhadap peningkatan kemampuan pemecahan masalah, dan (4) Terdapat interaksi antara pembelajaran dengan kemampuan awal terhadap peningkatan self-efficacy siswa, (5) proses pembelajaran siswa selama pembelajaran TGT berlangsung lebih baik dan (6) Bentuk jawaban siswa lebih bervariasi dan lebih baik selama pembelajaran TGT dibandingkan dengan pembelajaran biasa. Berdasarkan hasil penelitian ini, maka peneliti menyarankan agar pembelajaran matematika model TGT pada pembelajaran matematika dapat dijadikan alternatif bagi guru matematika untuk meningkatkan kemampuan pemecahan masalah matematik dan kecerdasan emosional siswa sebagai salah satu alternatif untuk menerapkan pembelajaran matematika yang inovatif.
\end{abstract}

Kata Kunci: model team games tournamnet, self-efficacy, proses pembelajaran, bentuk jawaban siswa.

\section{PENDAHULUAN}

Matematika merupakan bidang penting dalam menentukan kualitas suatu bangsa pendidikan dapat diterima dari lingkungan akademik maupun lingkungan masyarakat. Sekolah merupakan lingkungan akademik untuk memperoleh pendidikan formal. Pendidikan formal yaitu adanya mata pelajaran yang diberikan disekolah tersebut dan diatur oleh kurikulum. Menurut Trianto (2011) bahwa, "pendidikan bertujuan untuk mengembangkan potensi peserta didik agar menjadi manusia yang beriman dan bertaqwa kepada tuhan yang maha esa, berakhlak mulia, sehat, berilmu, cakap, kreatif, mandiri, dan menjadi warga negara yang demokratis serta bertanggung jawab".

Salah satu upaya dalam menguasai matematika yaitu melalui pembelajaran matematika di sekolah. Adapun tujuan pembelajaran matematika di sekolah yang disampaikan melalui Standar Isi Kurikulum Tingkat Satuan Pendidikan (KTSP), salah satunya pembelajaran matematika pada jenjang Sekolah Menengah Pertama (SMP) adalah sebagai berikut:

\footnotetext{
${ }^{1}$ Corresponding Author: Abdul Rasyid Fadhlan Khair Guru Matematika SMK NEGERI 9 MEDAN, 20127, Indonesia E-mail: abdlrasyid57@gmail.com
}

${ }^{2}$ Co-Author: Hamidah Nasution \& Asmin

Program Studi Pendidikan Matematika Universitas Negeri Medan, Medan, 20221, Indonesia
1. Memahami konsep matematika, menjelaskan keterkaitan antarkonsep dan mengaplikasikan konsep atau algoritma, secara luwes, akurat, efisien, dan tepat, dalam pemecahan masalah.

2. Menggunakan penalaran pada pola dan sifat, melakukan manipulasi matematika dalam membuat generalisasi, menyusun bukti, atau menjelaskan gagasan dan pernyataan matematika.

3. Memecahkan masalah yang meliputi kemampuan memahami masalah,merancang model matematika,

Dengan meninjau tujuan ini maka pembelajaran matematika hendaknya dilaksanakan secara tepat, sehingga tujuan-tujuan ini dapat tercapai. Upaya yang dapat dilaksanakan untuk mewujudkan tujuan pembelajaran matematika di sekolah yaitu dengan Sebagaimana yang dijelaskan BSNP (Badan Standar Nasional Pendidikan) dalam Permendiknas No. 22 Tahun 2006 bahwa "matematika merupakan ilmu universal yang mendasari perkembangan teknologi modern, mempunyai peran penting dalam berbagai disiplin dan memajukan kemampuan berpikir manusia".

Menurut NCTM (2000) "problem solving means engganging in a task for which the solution method is not known in advance". Kemampuan pemecahan masalah matematika itu sendiri bukan hanya tujuan dalam matematika belajar, tetapi juga sesuatu yang sangat

Pengembangan Perangkat Pembelajaran Matematika Menggunakan Model Team Games Tournament untuk Meningkatkan Kemampuan Pemecahan Masalah Siswa MTs 


\section{PARADIKMA JURNAL PENDIDIKAN MATEMATIKA}

Vol. 14, No. 1, Juni 2021

bermakna dalam kehidupan sehari-hari (Pinter, 2012), dan di dunia kerja menjadi kemampuan pemecahan masalah dapat memberikan manfaat (NCTM, 2000). Karena itu pembelajaran harus dikembangkan untuk mendidik siswa agar dapat menyadari dan memecahkan masalah yang mereka hadapi (Balim, 2009). Rendahnya hasil belajar matematika tersebut adalah suatu hal yang wajar dimana selama ini fakta di lapangan menunjukkan proses pembelajaran yang terjadi masih berpusat pada guru (teacher-centered).

Siswa lebih sering hanya diberikan rumus-rumus yang siap pakai tanpa memahami makna dari rumusrumus tersebut. Proses pembelajaran merupakan kegiatan yang bernilai edukatif. Nilai edukatif tersebut mewarnai interaksi yang terjadi antara guru dan siswa, siswa dengan siswa, siswa dengan sumber belajar dalam mencapai tujuan pembelajaran yang ditetapkan. Harapan yang ada pada setiap guru adalah bagaimana materi pelajaran yang disampaikan kepada anak didiknya dapat dipahami secara tuntas.

Dalam pendidikan formal, matematika merupakan salah satu bidang yang dipelajari oleh siswa. Matematika adalah bahasa yang melambangkan serangkaian makna dari pernyataan yang ingin kita sampaikan. Siswa diharapkan menggunakan matematika dan pola pikir matematis dalam kehidupan sehari-hari, dan belajar berbagai jenis sains yang menekankan aturan logis dan juga kemampuan menerapkan matematika (Saragih \& Napitupulu, 2015). Dengan kata lain, siswa diharapkan mampu meraih High Order Thinking Ability atau Higher Order Thinking Skills (HOTS). Dari uraian diatas, maka jelas bahwa matematika sangat penting untuk dipelajari, digeluti dan dikuasai dalam bidang pendidikan seperti disekolah.

Oleh karena itu pelajaran matematika di MTs PAB1 Helvetia diharapkan dapat dipelajari dengan benar dan tepat dalam proses pembelajaran sehingga manfaat dari matematika benar-benar dapat digunakan dan diaplikasikan dalam kehidupan siswa tersebut. Menurut Ibrahim (Trianto, 2011) perangkat yang digunakan dalam proses pembelajaran disebut dengan perangkat pembelajaran. Perangkat pembelajaran yang diperlukan dalam mengelola proses belajar mengajar dapat berupa: silabus, rencana pelaksanaan pembelajaran (RPP), lembar kerja peserta didik (LKPD), instrumen evaluasi atau tes hasil belajar (THB), buku guru, serta buku ajar siswa.

RPP merupakan pondasi dalam kegiatan belajar mengajar di kelas. Perencanaan pelaksanaan harus disusun sebaik mungkin agar kegiatan belajar mengajar berlangsung dengan baik. Pentingnya penyusunan RPP adalah untuk mengarahkan kegiatan belajar siswa dalam mencapai kompetensi dasar yang diinginkan, dimana setiap guru berkewajiban dalam menyusun RPP secara lengkap dan sistematis agar pembelajaran berlangsung secara interaktif, inspiratif, menyenangkan, menantang, efisien, memotifasi siswa untuk berpatisipasi aktif, serta memberikan ruang yang cukup bagi prakarsa, kreativitas, dan kemandirian sesuai dengan bakat, minat dan perkembangan fisik serta psikologi siswa.
Lembar kerja Peserta Didik (LKPD) merupakan salah satu alternatif bahan ajar yang dapat membantu siswa dalam proses belajarnya serta sebagai media pembelajaran yang mana didalamnya terdapat beberapa latihan soal. Hal ini dapat membiasakan siswa untuk melatih kemampuan belajarnya secara mandiri. Dengan adanya LKPD guru juga terbantu dalam proses pembelajaran yang terkadang butuh waktu yang cukup lama untuk menjelaskan materi yang ingin disampaikan dalam proses belajar mengajar.

Menurut Trianto (2013) Tes hasil belajar (THB) adalah tes yang digunakan untuk mengukur kemampuan siswa.Tes hasil belajar yang dikembangkan disesuaikan dengan jenjang kemampuan kognitif. Pentingnya tes hasil belajar ini adalah untuk mengetahui sejauh mana keberhasilan siswa dalam mengikuti proses belajar mengajar didalam kelas.

Namun pada kenyataannya merancang silabus dan RPP yang ideal, berkualitas dan dapat dipahami itu tidaklah mudah.Terkadang RPP yang telah dirancang oleh guru tidak sesuai dengan pelaksanaanya didalam kelas dikarenakan munculnya respon-respon siswa yang tidak terduga. Maka guru harus mempersiapkan beberapa kemungkinan yang akan terjadi selama proses belajar mengajar berlangsung sehingga respon siswa yang muncul tidak terabaikan, guru harus lebih siap dalam mengatasi segala kemungkinan yang akan terjadi. Selain itu peyajian LKPD juga terkesan monoton, kurang bervariasi dan hanya beisikan materi soal saja, dan tes hasil belajar yang sering diberikan guru tidak sesuai dengan kemampuan yang ingin dicapai. Namun pada kenyataannya merancang silabus dan RPP yang ideal, berkualitas dan dapat dipahami itu tidaklah mudah.Terkadang RPP yang telah dirancang oleh guru tidak sesuai dengan pelaksanaanya didalam kelas dikarenakan munculnya respon-respon siswa yang tidak terduga. Maka guru harus mempersiapkan beberapa kemungkinan yang akan terjadi selama proses belajar mengajar berlangsung sehingga respon siswa yang muncul tidak terabaikan, guru harus lebih siap dalam mengatasi segala kemungkinan yang akan terjadi. Selain itu peyajian LKPD juga terkesan monoton, kurang bervariasi dan hanya beisikan materi soal saja, dan tes hasil belajar yang sering diberikan guru tidak sesuai dengan kemampuan yang ingin dicapai.

Pengembangan perangkat pembelajaran ini mengacu pada model penelitian pengembangan yang disarankan oleh Thiagarajan, Semmel dan Semmel (Trianto, 2013) adalah model 4D yang terdiri dari 4 tahap yaitu: Define, Design, Develop, dan Desseminate. Dalam penulisan proposal ini, penulisan akan membahas kemampuan pemecahan masalah dan Self-efficacy. Dalam karakteristik pembelajaran abad 21, siswa diharapkan memiliki kreativitas sebagai kemampuan untuk memberikan gagasan-gagasan baru dengan menemukan banyak kemungkinan jawaban terhadap suatu masalah, yang menekankan pada segi kuantitas, ketergantungan dan keragaman jawaban dan menerapkannya dalam pemecahan masalah.

Menurut Pamungkas dan Masduki (2013) kemampuan pemecahan masalah matematika adalah kemampuan yang harus dimiliki siswa untuk dapat memahami masalah, merencanakan pemecahan, menyelesaikan masalah, dan memeriksa kembali hasil dari suatu masalah matematika 
Vol. 14, No. 1, Juni 2021

yang diberikan.

Pentingnya kemampuan pemecahan masalah oleh siswa dalam matematika dikemukakan oleh Branca (Syaipul, 2012), sebagai berikut: (1) kemampuan pemecahan masalah merupakan tujuan umum pengajaran matematika, bahkan sebagai jantungnya matematika; (2) pemecahan masalah meliputi metode, prosedur, dan strategi merupakan proses inti dan utama dalam kurikulum matematika; dan (3) pemecahan masalah merupakan kemampuan dasar dalam belajar matematika.

Pemecahan masalah merupakan komponen penting dari pendidikan matematika karena mudah digunakan secara individu maupun kelompok. NCTM (dalam Husna, dkk,. 2013) mengemukakan bahwa "pemecahan masalah merupakan proses menerapkan pengetahuan yang telah diperoleh sebelumnya pada situasi baru dan berbeda".

Sejalan dengan itu, menurut Murniati, dkk (2013) bahwa: "kemampuan pemecahan masalah akan memberikan bekal kemampuan bagi siswa untuk melanjutkan pendidikan maupun untuk menghadapi kehidupan dimasyarakat. Sedemikian penting peranan kemampuan pemecahan masalah sehingga pemecahan masalah dipandang sebagai tujuan utama dalam pembelajaran matematika".

Untuk mengetahui kemampuan memecahkan masalah, seorang siswa harus dihadapkan pada permasalahan matematika (soal matematika). Dengan menghadapi soal matematika, siswa akan berusaha untuk memecahkan masalah dengan menggunakan seluruh skema yang ada didalam dirinya. Menurut Elvina (2012) proses untuk menyelesaikan masalah tersebut disebut dengan pemecahan masalah. Menurut Webb (1979) pemecahan masalah melibatkan interaksi antara skema (pengetahuan) yang dimiliki oleh siswa dengan proses aplikasi yang menggunakan faktor kognitif dan afektif dalam memecahkan masalah.Untuk menyelesaikan masalah matematika diperlukan suatu cara atau suatu langkah-langkah yang sistematis agar proses penyelesaiannya menjadi mudah dan terarah. Hal ini sejalan dengan pendapat Pardimin dan Widodo (2016) bahwa untuk menyelesaikan masalah matematika, siswa dituntut untuk dapat berpikir secara sitematis.

Beberapa pendapat ahli tentang langkah-langkah yang dapat digunakan untuk menyelesaikan masalah matematika salah satunya adalah pemecahan masalah dari model Charles, Lester, \& O'Dafferyaitu: (1) Menuliskan apa yang diketahui dan ditanya dan membuat ilustrasi jika diperlukan (2) Memilih strategi yang cocok dengan merumuskan rencana yang bisa menghasilkan solusi yang benar tanpa kesalahan aritmetika dan (3) Menerapkan konsep matematis, melakukan perhitungan dengan tepat. (Szetala dan Nicol, 1992).

Fakta secara spesifik kemampuan pemecahan masalah siswa di sekolah masih rendah sesuai indikator kemampuan pemecahan masalah matematika menurut model Charles, Lester, \& O’Daffer. Hal ini ditunjukkan berdasarkan hasil observasi dilakukan tanggal 28 September 2019 di MTs PAB-1 Helvetia bahwa siswa masih merasa kesulitan dalam memahami dan menyelesaikan soal yang dirancang untuk melihat kemampuan pemecahan masalah siswa dengan memberikan soal kontekstual sederhana.

Penelitian menunjukkan bahwa kemampuan siswa untuk memecahkan masalah jauh dari kemampuan yang mereka miliki dalam berhitung karena siswa tidak tahu bagaimana cara memilih operasi yang benar untuk diterapkan pada masalah matematika tersebut. Namun kenyataan di lapangan menunjukkan bahwa Siswa belum dapat menyelesaikan masalah dengan baik yang menyebabkan hasil pembelajaran matematika belum memenuhi harapan.

Matematika masih dianggap sulit oleh sebagian besar siswa. Menurut Abdurrahman (2011) bahwa " dari berbagai bidang studi yang diajarkan disekolah, matematika merupakan bidang studi yang dianggap paling sulit oleh para siswa, baik yang tidak berkesulitan belajar dan lebih bagi siswa yang berkesulitan belajar"

Keadaan yang demikian harus diatasi dengan membiasakan dan melatih siswa menjawab soal-soal pemecahan masalah dikelas, aktivitas-aktivitas yang mencakup penyelesaian soal pemecahan masalah menurut Ruseffendi (1991) yaitu (1) merumuskan permasalahan dengan jelas; (2) menyatakan kembali dalam bentuk yang dapat diselesaikan; (3) menyusun hipotesis dan strategi penyelesaian; (4) melaksanakan prosedur penyelesaian; (5) melaksanakan evaluasi terhadap penyelesaian.

Untuk dapat menumbuh kembangkan kemampuan pemecahan masalah matematik, diperlukan suatu perangkat pembelajaran yang mendukung. Bertolak dari hal tersebut, adalah suatu tantangan bagi para guru untuk dapat mengembangkan perangkat pembelajarannya sendiri. Peraturan Pemerintah Nomor 19 (2005) yang berkaitan dengan standar nasional pendidikan mengisyaratkan bahwa guru diharapkan dapat mengembangkan perencanaan pembelajaran, yang kemudian dipertegas melalui Permendiknas Nomor 41 (2007) tentang standar proses. Untuk memenuhi standar proses tersebut, maka pembelajaran harus direncanakan, dinilai, dan diawasi.

Penggunaan perangkat pembelajaran di sekolah masih kurang dioptimalkan oleh para guru. Hal ini terlihat jelas dalam perangkat pembelajaran yang disusun oleh guru belum mencantumkan dan berbantuan media pembelajaran yang akan digunakan dalam kegiatan pembelajaran secara jelas dan terperinci. Sebagian guru hanya menuliskan media pembelajaran berupa slide persentasi yang sebenarnya kurang begitu menarik perhatian siswa. Dapat dilihat pada gambar berikut bahwasanya rata-rata setiap rencana pelaksanaan pembelajaran yang disusun oleh guru tidak mencantumkan media pembelajaran yang digunakan.

Selain menyusun perangkat pembelajaran dengan baik hal yang harus diperhatikan untuk meningkatkan kemampuan pemecahan masalahdan self efficacy siswa dan mengurangi tingkat kesulitan siswa dalam memahami materi matematika adalah dengan menggunakan suatu perangkat pembelajaran. Seperti yang disampaikan oleh Nusantara (2003) bahwa didalam menyampaikan materi pelajaran yang bersifat abstrak, seorang guru memerlukan alat bantu ajar atau alat peraga untuk memperjelas, mempermudah konsep atau bahkan mencapai sasaran 


\section{PARADIKMA JURNAL PENDIDIKAN MATEMATIKA}

Vol. 14, No. 1, Juni 2021

pengajaran yang diinginkan. Kesulitan penalaran materi matematika dapat disederhanakan dengan menggunakan perangkat pembelajaran.

Selain pentingnya kemampuan pemecahan masalah, hal ini yang dianggap penting adalah sikap siswa dalam mempelajari matematika yang salah satunya adalah self-efficacy siswa. Hal ini berarti self-efficacy adalah kepercayaan diri yang harus dimiliki oleh siswa. Dengan siswa memiliki sel-efficacy yang tinggi maka menjadikan siswa memiliki motivasi dalam menyelesaikan permasalahan terkait dengan pemecahan masalah.

Maka, dengan siswa memiliki self- efficacy yang tinggi dan pemecahan masalah merupakan hal yang sulit untuk dikerjakan maka peranan self-efficacy dapat membuat siswa untuk lebih tekun dan memiliki motivasi yang tinggi untuk dapat mengerjakannya. Jika seorang siswa memiliki kemampuan pemecahan masalah yang baik maka seorang siswa tersebut pun memiliki self-efficacy yang baik pula.

Self-efficacy merupakan aspek psikologi yang memberikan pengaruh besar dan signifikan terhadap keberhasilan siswa dalam menyelesaikan tugas - tugas dan pertanyaan-pertanyaan pemecahan masalah dengan baik. Secara umum self-efficacy memiliki arti kepercayaan diri atau keyakinan diri. Kemampuan menilai dirinya secara akurat merupakan hal yang sangat penting dalam mengerjakan tugas dan pertanyaan-pertanyaan yang diajukan guru, dengan kepercayaan diri atau keyakinan dirinya dapat memudahkan siswa dalam menyelesaikan tugas tersebut, bahkan lebih dari itu mampu meningkatkan prestasinya.

Sesuai hal tersebut Bandura (dalam Isnaini, 2011) penilaian kemampuan diri yang akurat merupakan hal yang sangat penting, karena perasaan positif yang tepat tentang sel-efficacy dapat mempertinggi prestasi, meyakini kemampuan. Mengembangkan motivasi internal, dan memungkinkan siswa untuk meraih tujuan yang menantang. Self-efficacy dapat mempengaruhi prestasi matematika hal tersebut diperkuat oleh pendapat Bandura, Barbaranelli, Caprara \& Pastorelli, 1996; Fast et al, Pajares, 2005 (Dalam Gilar, 2013) "Self-efficacy, a person's belief of their capabalities, has been shown to influence student's mathematical achievement".

Salah satu cara untuk menyelesaikan masalah adalah dengan penggunaan model pembelajaran yang sesuai. Salah satu model pembelajaran yang digunakan adalah model Teams Games Tournament (TGT). Sesuai dengan kurikulum 2013 yang mengedepankan pendekatan Scientific dimana siswa menemukan konsep matematik dari masalah. Beberapa ahli mengatakan bahwa model pembelajaran kooperatif tidak hanya unggul membantu siswa dalam memahami konsepkonsep yang sulit, tetapi juga menumbuhkan kerjasama, berpikir kritis dan mengembangkan sikap sosial siswa. Salah satu tipe model pembelajaran kooperatif yaitu tipe Teams Games Tournament (TGT) yang merupakan salah satu pembelajaran kooperatif yang mudah diterapkan, melibatkan aktivitas seluruh siswa tanpa ada perbedaan status, melibatkan peran siswa sebagai tutor sebaya dan mengandung unsur permainan dan reinforcement. Pembelajaran TGT bertujuan untuk meningkatkan kreatifitas belajar siswa khususnya dalam belajar matematika.

Teams Games Tournament (TGT) merupakan salah satu tipe dari model pembelajaran kooperatif. Pembelajaran TGT adalah salah satu tipe pembelajaran kooperatif yang mudah diterapkan, menyenangkan, melibatkan aktivitas siswa tanpa harus ada perbedaan status, melibatkan peran siswa sebagai tutor sebaya dan mengandung unsur permainan dan penguatan. Dalam TGT siswa memainkan permainan dengan anggota-anggota tim lain untuk memperoleh skor bagi tim mereka masingmasing. Permainan dapat disusun guru dalam bentuk turnamen berupa pertanyaan-pertanyaan yang berkaitan dengan materi pelajaran. Slavin (2010) berpendapat bahwa dalam TGT teman satu tim akan saling membantu dalam mempersiapkan diri untuk permainan dengan mempelajari lembar kegiatan dan menjelaskan masalah satu sama lain, tetapi sewaktu siswa sedang mengikuti permainan (game), temannya tidak boleh membantu. Hal ini untuk memastikan telah terjadi tanggung jawab individual.

\section{KAJIAN TEORITIS \\ Kemampuan Pemecahan Masalah}

Kemampuan pemecahan masalah merupakan salah satu kompetensi yang cukup penting bagi seseorang untuk bisa hidup. Esensi kehidupan sehari-hari adalah situasi pemecahan masalah. Sementara itu, banyak pemecahan masalah dalam kehidupan manusia dengan pendekatan matematis. Kemampuan pemecahan masalah sangat berhubungan dengan prestasi matematika, seperti hasil analisa PISA 2003 oleh Scherer dan Beckmann (2014) yang menyatakan: " math and science competence significantly contribute to problem solving across countries". Kutipan tersebut menyatakan bahwa kompetensi matematika dan sains secara signifikan berkontribusi terhadap pemecahan masalah diseluruh negara.

Dalam belajar matematika, pada umumnya yang dianggap masalah bukanlah soal yang biasa dijumpai siswa. Sugiyono(2009) mengemukakan bahwa "masalah diartikan sebagai penyimpangan antara yang seharusnya dengan apa yang benar-benar terjadi, antara teori dengan praktek, antara aturan dengan pelaksanaan, antara rencana dengan pelaksanaan".Senada dengan Siswono(2008) menyatakan "suatu masalah yaitu suatu kendala ketika suatu jawaban atau metode jawaban belum tampak jelas dan tidak tahu secara langsung apa yang harus dikerjakan untuk menyelesaikannya". Jika suatu masalah diberikan kepada seorang anak dan anak tersebut langsung mengetahui cara menyelesaikannya dengan benar, maka soal tersebut tidak dapat dikatakan sebagai masalah bagi anak tersebut.

Hudojo (2005) menyatakan bahwa masalah matematis adalah seseorang yang tidak mempunyai aturan/hukum tertentu yang segera dapat dipergunakan untuk menemukan jawaban atas suatu pertanyaan matematik"

Polya (1973) menggolongkan masalah matematik menjadi dua golongan, yaitu: “... problems 'to find' and problems 'to prove'. The aim of a problem to find, is a certain object, the unknown of the problem. The aim of a 
Vol. 14, No. 1, Juni 2021

problem to prove is to show conclusively that a certain clearly stated assertion is true, or else to show that it is false". ArtinyaProblem 'to find': bertujuan untuk menemukan suatu objek tertentu yang tidak dikenal dari masalah. Sedangkan problem 'to prove' bertujuan untuk memutuskan kebenaran suatu pernyataan, membuktikannya dan menyangkalnya.

Lebih lanjut lagi, syarat suatu masalah bagi seseorang siswa adalah : (1) pertanyaan yang dihadapkan kepada seorang siswa haruslah dapat dimengerti oleh siswa tersebut, namun pertanyaan itu harus merupakan tantangan baginya untuk menjawab dan (2) pertanyaan tersebut tidak dapat dijawab dengan prosedur rutin yang telah diketahui siswa.

Berdasarkan beberapa pendapat pakar tentang masalah yang telah dikemukakan di atas, maka dapat disimpulkan bahwa masalah matematis adalah suatu pertanyaan atau soal matematika yang tidak dapat dipecahkan oleh suatu prosedur rutin yang sudah diketahui sipelaku atau tidak punya aturan yang dapat digunakan untuk segera menemukan pemecahan soal tersebut.

Masalah timbul karena adanya suatu kesenjangan antara apa yang diharapkan dengan kenyataan, antara apa yang dimiliki dengan apa yang dibutuhkan, antara apa yang telah diketahui yang berhubungan dengan masalahtertentu dengan apa yang ingin diketahui. Oleh karena itu, kesenjangan ini harus segera diatasi. Proses mengenai bagaimana mengatasi kesenjangan ini disebut pemecahan masalah (problem solving).

Polya (1973) menyatakan bahwa pemecahan masalah adalah salah satu aspek tingkat tinggi, sebagai proses menerima masalahdan menyelesaikan masalah tersebut. Hal tersebut,senada denganLestari \&Yudhanegara (2015) mengatakan kemampuan pemecahan masalah adalah kemampuan menyelesaikanmasalah rutin, non-rutin, rutin nonterapan, non-rutin terapan, dan masalah non-rutin nonterapan dalam bidang matematika.

Hasratuddin (2015) mengatakan "kemampuanpemecahan masalah matematisadalah kemampuan untuk mengatasi kesulitan bermatematika dengan menggabungkan konsep-konsep dan aturanaturan matematika yang telah diperoleh sebelumnya untuk mencapai tujuan yang diinginkan". Selanjutnya,NCTM (2000) menambahkan istilah pemecahan masalah mengacu pada tugas matematika yang memiliki potensi untuk memberikan tantangan intelektual dan meningkatkan pemahaman pengembangan matematika siswa.

Menurut Nakin (2003) "pemecahan masalah merupakan proses yang menggunakan langkah-langkah tertentu (heuristik) yang membantu dalam menyelesaikan masalah".Selanjutnya, Schoenfeld (1992) mengatakan "pemecahan masalah meliputi mengerti permasalahan (resources), mengupayakan apa yang dilakukan untuk menyelesaikan masalah (heuristics), menyusun penyelesaian masalah (belief systems) dan menyelesaikan permasalahan (control)".

Ruseffendi (1991) mengemukakantujuan pemecahan masalah diberikan kepada siswa sebagai berikut: a. Dapat menimbulkan keingintahuan dan adanya motivasi, menumbuhkan sifat kreativitas.

b. Di samping memiliki pengetahuan dan keterampilan (berhitung, dan lain-lain), disyaratkan adanya kemampuan untuk terampil membaca dan membuat pernyataan yang benar.

c. Dapat menimbulkan jawaban yang asli, baru, khas, dan beraneka ragam, dan menambah pengetahuan baru.

d. Meningkatkan aplikasi dari ilmu pengetahuan yang sudah diperolehnya.

e. Mengajak siswa untuk memiliki prosedur pemecahan masalah, mampu membuat analisis dan sintesis, dan dituntut untuk membuat evaluasi terhadap hasil pemecahannya.

f. Merupakan kegiatan yang penting bagi siswa yang melibatkan bukan saja satu bidang studi tetapi (bila diperlukan) banyak bidang studi, dapat melibatkan pelajaran di luar pelajaran sekolah, merangsang siswa untuk menggunakan segala kemampuannya. Ini penting bagi siswa untuk menghadapi kehidupan kini dan dikemudian hari.

\section{METODE PENELITIAN Jenis Penelitian}

Berdasarkan rumusan masalah dan tujuan penelitian yang ditetapkan, maka penelitian ini dikategorikan ke dalam jenis penelitian pengembangan (development research). Penelitian ini menggunakan model pengembangan 4-D (define, design, develop, dan disseminate) Thiagarajan, Semmel dan Semmel (1974) dengan mengembangkan perangkat pembelajaran dengan model pembelajaran berbasis masalah. Pengembangan ini dilaksanakan untuk menghasilkan perangkat pembelajaran menggunakan model Teams Games Tournament (TGT) yang selanjutnya akan diujicobakan di kelas dengan menggunakan desain The One-Class Pretest-Posttest Design, dengan tidak menggunakan kelas pembanding namun sudah menggunakan tes awal sehingga besarnya peningkatan kemampuan pemecahan masalah dan self efficacy siswa dapat diketahui secara pasti.

Tahap define adalah tahap untuk menetapkan dan mendefinisikan syarat-syarat pembelajaran. Tahap define ini mencakup lima langkah pokok, yaitu analisis siswa (learner analysis), analisis kebutuhan media, analisis konsep (concept analysis) dan perumusan tujuan pembelajaran (specifying instructional objectives) dan perumusan perangkat pembelajaran.

1. Analisis Siswa (learner analysis)

Menurut Thiagarajan dan Semmel (1974), analisis siswa merupakan telaah tentang karakteristik siswa yang sesuai dengan desain pengembangan perangkat pembelajaran menggunakan model Teams Games Tournament (TGT). Analisis siswa dalam penelitian ini merupakaan telaah tentang karakteristik siswa kelas Madrasah Tsanawiyah Negeri 2 Medan yang sesuai dengan rancangan dan pengembangan materi. Karakteristik itu meliputi latar belakang kemampuan akademik (pengetahuan) perkembangan kognitif, serta keterampilan-keterampilan individu atau sosial yang berkaitan dengan topik pembelajaran, media, format dan bahasa yang dipilih. Analisis siswa dilakukan untuk mendapatkan gambaran karakteristik siswa, antara lain: (1) 


\section{PARADIKMA JURNAL PENDIDIKAN MATEMATIKA}

Vol. 14, No. 1, Juni 2021

tingkat kemampuan atau perkembangan intelektualnya (2) keterampilan-keterampilan individu atau sosial yang sudah dimiliki dan dapat dikembangkan untuk mencapai tujuan pembelajaran yang ditetapkan.

2.Analisis kebutuhan

Masalah yang dihadapi oleh guru pada MTsN 2 Medan yaitu salah satunya kesulitan dalam mengembangkan perangkat pembelajaran. Mereka cenderung tidak memiliki banyak waktu, kesulitan menjabarkan materi segiempat dan kesulitan dalam menentukan metode mengajar untuk mengembangkan perangkat pembelajaran. Sedangkan masalah dari siswa Madrasah Tsanawiyah yaitu kesulitan siswa dalam memahami materi pembelajaran yang diakibatkan oleh kesulitan guru dalam mengembangkan perangkat pembelajaran khususnya pada materi segiempat Madrasah Tsanawiyah.

Untuk mengatasi masalah yang dihadapi oleh guru dan siswa tersebut dilakukan penelitian di MTsN 2 Medan untuk mengembangkan perangkat pembelajaran pada mata pelajaran matematika pokok bahasan segiempat.

\section{Analisis Konsep (concept analysis)}

Untuk mendukung analisis ini, analisis-analisis yang perlu dilakukan adalah menganalisis materi pelajaran yang ditujukan kepada MTsN 2 Medan pada penelitian ini yaitu materi segiempat Kemudian menyusunnya kedalam bentuk hirarki dan merinci konsep-konsep individu kedalam hal yang kritis dan relevan.

4. Perumusan Tujuan Pembelajaran (Specifying instructional objectives)

Perumusan tujuan pembelajaran merupakan acuan dalam merancang perangkat pembelajaran menggunakan model TGT. Perumusan tujuan pembelajaran ini dilakukan untuk menjabarkan indikator pencapaian hasil belajar menjadi indikator yang lebih spesifik yang disesuaikan berdasarkan hasil analisis materi dan analisis tugas yang telah dilakukan sebelumnya. Indikator/tujuan pembelajaran disesuaikan dengan kompetensi inti dan kompetensi dasar pada kurikulum 2013.

Tahap perancangan bertujuan untuk merancang perangkat pembelajaran. Terdapat empat langkah pada tahap ini :

1) Constructing criterion- referenced test (menyusun kriteria-referensi tes)

Langkah ini merupakan jembatan yang menghubungkan tahap I dan tahap II. Kriteria yang dikembangkan mengkonversi tujuan menjadi kerangka dari materi pembelajaran.

2) Media selection (pemilihan media)

Pemilihan media yang sesuai untuk menyajikan isi dari pembelajaran. Proses ini mencakup penyesuaian analisis konsep dan analisis tugas dengan karakter dari siswa, sumber produksi, rencana penyebaran berkenaan dengan sifat-sifat media.

3) Format selection (pemilihan format)

Langkah ini sangat terkait dengan pemilihan media sebelumnya. Istilah format pembelajaran sendiri mengacu pada kombinasi media, strategi mengajar, dan teknik penggunaan. Sebagai contoh: format visual, format audiovisual, format non verbal, dan lainlain. Pemilihan format yang sesuai ini tergantung pada banyaknya faktor-faktor yang didiskusikan.

4) Initial design (pendesainan awal)

Menyajikan hal-hal dasar dari pembelajaran melalui media yang tepat dan dalam urutan yang sesuai. Langkah ini juga mencakup menyusun berbagai kegiatan belajar seperti membaca buku, mewawancarai siswa tertentu, dan menerapkan keahlian yang berbeda dengan memperhatikan setiap siswa.

Pada tahap pengembangan ini bertujuan untuk menghasilkan perangkat pembelajaran menggunakan model TGT yang baik yang telah direvisi berdasarkan masukan para ahli (validator) dan data yang diperoleh dari uji coba lapangan. Tahap pengembangan ini dilakukan oleh peneliti guna menganalisis, menguji coba, mengembangkan, mengevaluasi dan merevisi perangkat pembelajaran yang dirancang. Terdapat dua langkah yang dilakukan pada tahap ini, yaitu :

a. Validasi penilaian ahli

Validasi terhadap perangkat pembelajaran dilakukan untuk mengetahui kelayakan perangkat pembelajaran, validasi dilakukan oleh beberapa ahli. Ahli yang dimaksud adalah validator yang berkompeten untuk menilai pembelajaran dan memberikan masukan atau saran guna menyempurnakan perangkat pembelajaran yang telah dibuat.

Penilaian para ahli meliputi validasi isi yang mencakup semua perangkat pembelajaran yang telah dikembangkan pada tahap perancangan draft I, sehingga menghasilkan draft II yang layak digunakan. Hasil validasi para ahli digunakan sebagai dasar melakukan revisi dan penyempurnaan perangkat pembelajaran dan instrument. Secara umum validasi meliputi : Format, bahasa, ilustrasi, isi (materi) dan tujuan pembelajaran.

b. Uji coba lapangan

Setelah diperoleh perangkat dan media pembelajaran yang valid dari ahli, selanjutnya dilakukan uji coba di MTsN 2 Medan. Tahap ini dilakukan untuk melihat efektivitas perangkat pembelajaran yang telah dikembangkan.

Adapun rancangan uji coba yang digunakan dalam penelitian ini adalah one shot case study atau disebut juga dengan one group posttest-only design. Rancangan penelitian one shot case study ini dipresentasikan pada tabel 1.

Tabel 1. Rancangan Uji Coba

\begin{tabular}{cc}
\hline Treatment & Posttest \\
\hline $\mathrm{X}$ & $\mathrm{O}$
\end{tabular}

Sumber : (Sugiyono, 2016)

Keterangan :

$\mathrm{O}=$ posttest kemampuan pemecahan masalah matematis $\mathrm{X}=$ Treatment dengan perangkat pembelajaran

Data yang diperoleh dari hasil uji coba I dianalisis dan dijadikan acuan revisi perangkat pembelajaran untuk uji coba berikutnya sampai diperoleh kesimpulan bahwa kriteria efektif telah terpenuhi. Pada setiap tahap uji coba akan dicatat data yang diperlukan yaitu bagaimana kemampuan pemecahan masalah siswa, bagaimana respon siswa selama pembelajaran, bagaimana peningkatan kemampuan pemecahan masalah matematis dan Self 
Vol. 14, No. 1, Juni 2021

Efficacy siswa dari uji coba pertama dan uji coba berikutnya. Pada akhir uji coba akan diperoleh perangkat final (draft final).

\section{HASIL PENELITIAN DAN PEMBAHASAN Hasil Penelitian}

Penelitian ini merupakan penelitian pengembangan (development research). Produk yang dikembangkan pada penelitian ini adalah perangkat pembelajaran sehingga memenuhi kriteria validitas, kepraktisan dan keefektivan. Perangkat pembelajaran yang dikembangkan meliputi rencana pelaksanaan pembelajaran (RPP), lembar kerja peserta didik (LKPD), buku siswa, dan buku guru. Perangkat pembelajaran dikembangkan dengan menggunakan model pengembangan 4-D dari Thiagarajan. yang meluputi empat tahapan yaitu pendefenisian, perancangan, pengembangan dan penyebaran. Setiap tahap dilakukan secara berkesinambungan. Selanjutnya pengembangan perangkat pembelajaran dalam penelitian ini adalah dengan model team games tournament yang bertujuan untuk meningkatkan kemampuan pemecahan masalah dan self-efficacy siswa.

Pada proses pengembangan perangkat pembelajaran yang berguna untuk mendapatkan perangkat pembelajaran yang valid, praktis dan efektif dilakukan beberapa kegiatan seperti validasi, revisi dan uji coba dengan menggunakan perangkat pembelajaran yang telah dikembangkan serta instrumen-instrumen sebagai alat ukur perangkat pembelajaran dengan aturan dan kriteria yang telah ditetapkan pada bab III.

Berdasarkan hasil observasi dan analisis terhadap perangkat pembelajaran di Madrasah Tsanawiyah Swasta PAB-1 Helvetia, menunjukkan bahwa selama ini guru belum memiliki perangkat pembelajaran yang baik. Rencana pelaksanaan pembelajaran (RPP) yang ada bukan merupakan gambaran dari proses pembelajaran yang dilaksanakan. LKPD yang ada digunakan tidak singkron dengan RPP, sehingga tujuan pembelajaran yang diinginkan pada RPP tidak terdapat dalam LKPD yang ada, dan buku pegangan yang digunakan tidak memuat soal-soal yang kontekstual. Selain itu, dalam proses pembelajaran siswa tidak dilibatkan dalam proses menemukan pengetahuannya melainkan langsung diberikan oleh guru. Hal ini yang diduga menjadi penyebab kemampuan pemecahan masalah dan self efficacy siswa masih rendah.

Berdasarkan uraian di atas, terlihat bahwa ada masalah dalam proses pembelajaran matematika di Madrasah Tsanawiyah Swasta PAB-1 Helvetia. Untuk mengatasi masalah tersebut perlu dikembangkan perangkat pembelajaran model TGT. Dengan mengembangkan perangkat pembelajaran model TGT, siswa dilatih untuk bernalar dan percaya diri dalam menyelesaikan masalah-masalah yang diberikan. Dengan demikian kemampuan pemecahan masalah dan self efficacy siswa bisa meningkat. Perangkat pembelajaran yang dikembangkan berupa RPP, buku guru, buku siswa dan tes hasil belajar berupa tes kemampuan pemecahan masalah dan angket selfefficacy siswa.
Setelah perangkat pembelajaran yang dikembangkan telah memenuhi kriteria kevalidan menurut ahli. Maka selanjutnya perangkat pembelajaran dalam bentuk draf I ini diujicobakan di lapangan tempat penelitian yaitu siswa-siswi kelas VII Madrasah Tsanawiyah Swasta PAB-1 Helvetia .

Uji coba I ini dilakukan sebanyak 3 kali pertemuan sesuai dengan rencana pelaksanaan pembelajaran (RPP) yang telah dikembangkan dengan jumlah 26 orang. Pada uji coba ini dilakukan untuk mengukur kepraktisan dan keefektifan perangkat pembelajaran (draf $I$ ) yang dikembangkan berbasis model TGT yang bertujuan untuk meningkatkan kemampuan pemecahan masalah dan selfefficacy siswa. Dalam uji coba ini, peneliti bertindak sebagai guru yang mengajar, uji coba juga diikuti 2 orang pengamat yang mempunyai tugas mengamati aktivitas siswa dan kemampuan guru mengelola pembelajaran.

Dalam proses pembelajaran, siswa dikelompokkan 56 siswa dalam satu kelompok. Pemilihan anggota kelompok dilakukan heterogen dalam jenis kelamin maupun kemampuan akademik dalam matematika. Jadi anggota setiap kelompok terdiri dari siswa laki-laki dan perempuan serta siswa dengan kemampuan akademik tinggi, sedang maupun rendah. Oleh karena itu, dapat dikatakan bahwa karakteristik dan kemampuan rata-rata tiap kelompok relatif sama.

Berdasarkan rumus korelasi product moment, diperoleh validitas setiap butir pre-tes dan post-test disajikan pada Tabel 4.8 dan Tabel 4.9 sebagai berikut:

Dalam menentukan persentase waktu ideal aktivitas siswa peneliti dibantu oleh dua orang pengamat yang mengamati aktivitas siswa sesuai dengan indikatorindikator persentase pencapaian waktu ideal aktivitas siswa yang telah dijabarkan pada bab III dan lembar pengamatan terlampir pada lampiran. Hasil perolehan persentase pencapaian waktu ideal aktivitas untuk empat kali pertemuan secara lengkap dapat dilihat pada lampiran D. Berikut ini akan dijabarkan secara singkat persentase pencapaian waktu ideal aktivitas siswa.

Sedangkan proporsi waktu paling sedikit terlihat pada indikator keenam yaitu aktivitas siswa yang tidak relevan dengan kemampuan pemecahan masalah hanya sebesar $3,1 \%$. Dari hasil tersebut dapat dilihat bahwa siswa-siswa selama proses pembelajaran sudah dapat melakukan halhal yang telah ditetapkan sehingga hal-hal yang tidak relevan dengan pembelajaran tidak terlihat secara signifikan.

Selanjutnya hasil pencapaian waktu yang diperoleh dirujuk pada kriteria yang telah ditetapkan pada bab III sebelumnya. Dari hasil di atas dapat disimpulkan bahwa aktivitas siswa telah mencapai persentase pencapai waktu ideal, dari keenam indikator di atas terlihat bahwa persentase aktivitas siswa masih berada pada ambang batasan persentase pencapaian waktu ideal atau interval toleransi waktu kategori yang telah ditetapkan.

Angket respon siswa ini dilakukan untuk melihat sejauh mana ketertarikan siswa, perasaan senang dan keterkinian serta kemudahan dalam memahami komponenkomponen seperti materi/isi perangkat pembelajaran, format, gambar-gambarnya, kegiatan dalam lembar aktivitas siswa dan suasana belajar. Angket respon siswa ini diberikan ketika seluruh kegiatan belajar mengajar

Pengembangan Perangkat Pembelajaran Matematika Menggunakan Model Team Games Tournament untuk Meningkatkan Kemampuan Pemecahan Masalah Siswa MTs 
Vol. 14, No. 1, Juni 2021

selesai dilaksanakan.

Respon siswa terhadap pembelajaran dan perangkat pembelajaran yang digunakan di dalam pembelajaran meliputi respon positif dan respon negatif. Respon positif ditandai dengan pernyataanpernyataan positif seperti senang, baru, berminat terhadap komponen perangkat pembelajaran yang dikembangkan berbasis masalah. Sedangkan pernyataan negatif ditandai dengan pernyataanpernyataan seperti tidak senang, tidak baru dan tidak berminat dalam menggunakan komponen perangkat pembelajaran yang dikembangkan berbasis masalah.

Berdasarkan kedua kriteria kepraktisan diperoleh bahwa tim ahli menyatakan bahwa perangkat pembelajaran dapat digunakan dengan revisi kecil dan respon siswa juga telah memenuhi kriteria yang telah ditentukan pada BAB III. Maka perangkat pembelajaran model TGT yang dikembangkan telah dikatakan

Bedasarkan kritera perangkat pembelajaran yang dikatakan efektif, maka perangkat pembelajaran yang digunakan belum efektif. Hal tersebut karena kemampuan pemecahan masalah belum memenuhi kriteria yang ditentukan walaupun efisiensi waktu pembelajaran telah terpenuhi sehingga perlunya dilakukan uji coba II.

Tabel 2. Rangkuman Hasil N-Gain Kemampuan Pemecahan Masalah Uji Coba I

\begin{tabular}{ccc}
\hline $\boldsymbol{N}$-Gain & Interpretasi & Jumlah Siswa \\
\hline $\mathrm{g}>0,7$ & Tinggi & 2 \\
\hline $0,3<\mathrm{g} \leq 0,7$ & Sedang & 17 \\
\hline $\mathrm{g} \leq 0,3$ & Rendah & 7 \\
\hline
\end{tabular}

Nilai $N$-Gain sebesar 0,4 jika diinterpretasikan ke dalam klasifikasi yang telah diuraikan pada BAB III, maka total peningkatan kemampuan pemecahan masalah pada uji coba I yang diperoleh berada dalam kategori "sedang" atau dengan persentase Gain $40 \%$.

Nilai $N$-Gain perindikator kemampuan pemecahan masalah masing-masing adalah 0,$4 ; 0,5$ dan 0,14 . Indikator yang paling rendah peningkatannya adalah indikator ketiga dengan nilai $N$-Gain 0,14 yakni : Menyelesaikan masalah Sedangkan indikator yang mengalami peningkatan tertinggi adalah indikator ketiga dengan nilai $\mathrm{N}$-Gain 0,5 yaitu Merencanakan Pemecahan Masalah.

N-Gain digunakan dalam penelitian ini untuk menghindari bias dari hasil penelitian yang telah dilakukan. Misalnya dilihat pada Tabel 4.18. pada S-4 dan S-20. Pada S- 4 peningkatan nilai pretest dan posttest yang diperoleh sebesar 10 dari nilai 65 pada pretest dan nilai 75 pada posttest. Pada S-20 peningkatan pretest dan posttest yang diperoleh sebesar 17,5 yaitu dari nilai 42,5 pada pretest dan nilai 60 pada posttest. Dari hasil dapat dilihat bahwa S-20 memiliki peningkatan yang lebih tinggi dari hal tersebut akan menimbulkan bias terhadap penelitian ini, karena dari hasil pretest kedua siswa ini sudah berbeda. Sehingga untuk menghindari bias pada hasil penelitian ini dilakukan peninjauan berdasarkan nilai gain yang dinormalisasi (N-Gain) antara S-4 dan S-20 ternyata N praktis.

Gain yang didapat adalah sama yaitu 0,3 yang dikategorikan "sedang".

Jika dilihat kembali pada Tabel 4.18 pada S-7 dan S-25 dimana kedua siswa tersebut memiliki nilai posttest yang sama yaitu sebesar 75. Akan tetapi memiliki nilai pretest yang berbeda dimana S-7 nilai pretesnya sebesar 57,5 sedangkan S-25 nilai pretestnya sebesar 65, kemudian peningkatan dari S-7 dan S-25 juga berbeda yaitu pada S-7 meningkat sebesar 17,5 dan pada S-25 meningkat sebesar 10 dari hasil penelitian ini juga akan dapat menimbulkan bias. Sehingga untuk menghindari bias pada hasil penelitian ini dilakukan peninjauan berdasarkan nilai gain yang dinormalisasi (N-Gain) antara S-7 dan S-25 ternyata nilai gain yang didapat $\mathrm{S}-7$ sebesar 0,4 yang dikategorikan "sedang" dan nilai gain yang didapat S-25 sebesar 0,3 yang dikategorikan "sedang".

Jika dilihat lagi pada Tabel 4.18. pada S-21 dan S-23 dimana kedua siswa tersebut memiliki peningkatan yang sama yaitu sebesar 12,5. Akan tetapi memiliki nilai pretest dan posttest yang berbeda dimana S-21 nilai pretestnya sebesar 62,5 dan nilai posttestnya 75 sedangkan S-23 nilai pretestnya sebesar 45 dan nilai posttestnya 57,5 , dari hasil penelitian ini juga akan dapat menimbulkan bias. Sehingga untuk menghindari bias pada hasil penelitian ini dilakukan peninjauan berdasarkan nilai gain yang dinormalisasi $(\mathrm{N}$ Gain) antara S-21 dan S-23 ternyata nilai gain yang didapat S-21 sebesar 0,3 yang dikategorikan "sedang" dan nilai gain yang didapat S-23 sebesar 0,2 yang dikategorikan "rendah".

Berdasarkan tabel 4.18 dan 4.19 di atas dapat dilihat bahwa 2 orang siswa mendapat skor $N$-Gain pada rentang $>0,7$ atau mengalami peningkatan kemampuan pemecahan masalah dengan kategori "Tinggi". Untuk siswa yang mengalami peningkatan kemampuan pemecahan masalah matematis dengan kategori "Sedang" atau mendapat skor $N$-Gain $0,3<\mathrm{g} \leq 0,7$ berjumlah 17 orang dan 7 orang yang mendapat skor $N$-Gain $\mathrm{g} \leq 0,3$ atau mengalami peningkatan kemampuan pemecahan masalah dengan kategori "Rendah".

Data angket self efficacy siswa dikumpulkan dan dianalisis untuk mengetahui kemampuan self efficacy siswa sebelum perlakuan pembelajaran. Pilihan jawaban dari butir angket self efficacy menggunakan skala linkert. Jenis data yang diperoleh dari jawaban angket tersebut adalah skala ordinal. Perhitungan dengan Metode Suksesif Interval dilakukan dengan menggunakan software Ms. Excel 2007. Keseluruhan hasil analisis dapat dilihat pada lampiran. Hasil analisis deskriptif terhadap self efficacy siswa setelah menggunakan perangkat pembelajaran disajikan pada Tabel 4.20 di bawah ini:

Tabel 3. Deskripsi Data Self Efficacy Siswa Setelah Menggunakan Perangkat Pembelajaran Pada Uji Coba I

\begin{tabular}{ccc}
\hline \multirow{2}{*}{ Kelompok } & Data Statistik & $\begin{array}{c}\text { Self-efficacy Setelah } \\
\text { Menggunakan } \\
\text { Perangkat }\end{array}$ \\
\hline \multirow{2}{*}{ Tinggi } & $\mathrm{N}$ & 6 \\
\cline { 2 - 3 } & Rata-rata & 95,83 \\
\cline { 2 - 3 } Sedang & Standar Deviasi & 0,7 \\
\cline { 2 - 3 } & Rata-rata & 15 \\
\cline { 2 - 3 } & Standard Deviasi & 71,86 \\
\hline
\end{tabular}

Pengembangan Perangkat Pembelajaran Matematika Menggunakan Model Team Games Tournament untuk Meningkatkan Kemampuan Pemecahan Masalah Siswa MTs 


\begin{tabular}{|c|c|c|c|}
\hline \multirow{3}{*}{ Rendah } & $\mathrm{N}$ & 5 & kelemahan perangkat pada uji coba I. \\
\hline & Rata-rata & 55 & Revisi terhadap RPP akan diarahkan agar pembelajaran \\
\hline & Standard Deviasi & 1,87 & dapat lebih meningkatkan kemampuan pemecahan \\
\hline \multirow{3}{*}{ Keseluruhan } & $\mathrm{N}$ & 26 & masalah khususnya pada aspek memahami da \\
\hline & Rata-rata & 74,15 & merencanakan masalah. Selain itu revisi RPP juga aka \\
\hline & Standard Deviasi & 15,9 & mengacu pada peningkatan self-efficacy siswa. \\
\hline
\end{tabular}

Secara deskriptif dapat disimpulkan bahwa self efficacy siswa setelah menggunakan perangkat pembelajaran model TGT yang telah dikembangkan berdasarkan kategori KAM (Tinggi, sedang dan rendah) menghasilkan siswa yang memiliki self-efficacy pada kelompok tinggi terdapat 6 orang, pada kelompok sedang terdapat 15 orang siswa dan pada kelompok rendah terdapat 5 orang siswa. Rata-rata kemampuan self efficacy siswa masing-masing adalah 95,83, 71,86 dan 55.

Setelah perangkat pembelajaran model TGT diuji cobakan pada uji coba pertama, maka peneliti meihat kelemahan-kelemahan yang terdapat pada perangkat pembelajaran pembelajaran model TGT yang dikembangkan. Kelemahan-kelemahan tersebut adalah :

a. Pada RPP terdapat alokasi waktu dalam tahap mengorganisasikan siswa untuk belajar yaitu 15 menit dianggap terlalu lama dan waktu pada tahap membimbing penyelidikan individual maupun kelompok yaitu 20 menit dianggap terlalu cepat, karena banyak kelompok yang belum siap untuk menyelesaikan LKPD yang telah dibagikan.

b. Pada buku guru dan siswa terdapat kalimat yang kurang jelas, salah satunya terletak pada informasi yang terdapat pada maslah 1.3 "menentukan rumus luas segiempat" kalimat tersebut membingungkan siswa sehingga ditambahkan keterangan menjadi “ mari menentukan rumus dan luas bangun datar segiempat berikut"

c. Pada LKPD ke III tepatnya pada permasalahan ke 3 dinilai kurang efektif dari segi alokasi waktu dikarenakan pada LKPD III permasalahan yang diberikan membutuhkan pembahasan yang cukup kompleks berdampak pada alokasi waktu yang diberikan, fakta dilapangan menunjukkan ketika dilakukan uji coba I para peserta didik tidak dapat mengerjakan hingga permasalahan ke 3 karena keterbatasan waktu, oleh karena itu pada LKPD III permasalahan 3 dihapuskan sehingga terdapat hanya 2 permasalahan.

Berdasarkan hasil analisis perangkat pembelajaran pada uji coba I diperoleh data yang menunjukkan bahwa perangkat pembelajaran belum dapat dikatakan efektif. Untuk itu sebelum dilakukan uji coba 2, maka akan dilakukan revisi terhadap perangkat pembelajaran yang digunakan pada uji coba I. Revisi akan dilakukan berdasarkan kelemahan-kelemahan perangkat pada uji coba I. Berdasarkan hasil analisis perangkat pembelajaran pada uji coba I diperoleh data yang menunjukkan bahwa perangkat pembelajaran belum dapat dikatakan efektif. Untuk itu sebelum dilakukan uji coba 2, maka akan dilakukan revisi terhadap perangkat pembelajaran yang digunakan pada uji coba I. Revisi akan dilakukan berdasarkan kelemahantahap mengorganisasikan siswa untuk belajar yaitu 15 menit dianggap terlalu lama dan waktu pada tahap membimbing penyelidikan individual maupun kelompok yaitu 20 menit dianggap terlalu cepat, karena banyak kelompok yang belum siap untuk menyelesaikan LKPD yang telah dibagikan. Oleh sebab itu, waktu pada tahap mengorganisasikan siswa untuk belajar dikurangi 5 menit, sehingga menjadi 10 menit. Selanjutnya waktu pada tahap membimbing penyelidikan individual maupun kelompok ditambah 5 menit menjadi 25 menit.

Revisi pada buku guru dan siswa salah satunya terletak pada informasi yang terdapat pada Pada buku guru dan siswa yang terdapat kalimat kurang jelas, salah satunya terletak pada informasi yang terdapat pada maslah 1.3 "menentukan rumus luas segiempat" kalimat tersebut membingungkan siswa dikarenakan siswa terus menanyakan apa yang dimaksud dengan rumus luas segiempat sehingga ditambahkan keterangan sifat-sifat .

Revisi Pada LKPD terletak pada LKPD ke III tepatnya pada permasalahan ke 3 yang dinilai kurang efektif dari segi alokasi waktu dikarenakan pada LKPD III permasalahan yang diberikan membutuhkan pembahasan yang cukup kompleks hal tersebut berdampak pada alokasi waktu yang diberikan, fakta dilapangan menunjukkan ketika dilakukan uji coba I para peserta didik tidak dapat mengerjakan hingga permasalahan ke 3 karena keterbatasan waktu, oleh karena itu pada LKPD III permasalahan 3 dihapuskan sehingga terdapat hanya 2 permasalahan.

\section{KESIMPULAN}

Berdasarkan hasil analisis dan pembahasan dalam penelitian ini, dikemukakan bahwa perangkat pembelajaran model Team Games Tournament untuk meningkatkan kemampuan pemecahan masalah dan selfefficacy siswa yang dikembangkan sudah memenuhi kriteria valid, praktis dan efektif, yakni :

a. Kevalidan dengan rata-rata validitas RPP sebesar 4,27, rata-rata validitas lembar aktivitas siswa sebesar 4,26, rata-rata validitas buku guru sebesar 4,25, rata-rata validitas buku siswa sebesar 4,28, dengan kategori valid.

b. Kepraktisan ditinjau dari 1) Respon tim ahli atau validator yang menyatakan bahwa perangkat pembelajaran dapat digunakan dengan revisi kecil 2) Keterlaksanaan perangkat pembelajaran model Team Games Tournament pada kriteria $I O=4,35$ tinggi.

c. Keefektifan ditinjau dari 1) Ketuntasan klasikal mencapai $88 \%$ yakni telah memenuhi kriteria ketuntasan yakni $\geq 85 \%$ siswa mencapai KKM. 2) Kemampuan guru dalam mengelola pembelajaran diperoleh rata-rata 4,08 atau dalam kategori "baik". 3) Pencapaian persentase waktu ideal aktivitas siswa berada dalam pencapaian waktu ideal aktivitas siswa 
dengan toleransi waktu 5\%. .4) Respon siswa terhadap pembelajaran diperoleh rata-rata 95,02\%.

Berdasarkan hasil penelitian dan kesimpulan di atas, maka dapat disarankan beberapa hal sebagai berikut:

1. Para guru agar dapat menggunakan perangkat matematika berdasarkan pembelajaran model Team Games Tournamnet dan instrumen sebagai alternatif pembelajaran di dalam kelas karena perangkat tersebut telah efektif dan dapat meningkatkan kemampuan pemecahan masalah dan self-eficacy siswa dengan aspek tertinggi yaitu generality.

2. Penelitian dan pengembangan berupa perangkat pembelajaran menggunakan model Thiagarajan, Semmel dan Semmel dapat dijadikan alternatif bagi pengembangan perangkat pembelajaran untuk mata pelajaran matematika maupun mata pelajaran lainnya karena model Thiagarajan sangat mudah untuk dilaksanakan dan langkah-langkah pelaksanaan pengembangan sangat jelas serta terstruktur.

3. Peneliti menyarankan kepada peneliti lain yang melakukan penelitian sejenis untuk lebih memperhatikan kecocokan antar siswa dalam kelompok karena pada pembentukan kelompok diskusi pada penelitian ini, peneliti hanya memperhatikan pemerataan kelompok tinggi, sedang dan rendah saja sehingga dapat menghambat terjadinya interaksi antar siswa.

4. Peneliti menyarankan agar pengembangan perangkat model Team Games Tournament dapat digunakan pada kelas yang lebih tinggi.

Jumlah pertemuan dapat ditambah agar dapat lebih memastikan data yang didapat lebih tepat.

\section{REFERENSI}

Akker, J.V.D. 1999. Principles and Methods of Development Research. Dalam Plomp, T; Nieveen, N; Gustafson, K; Branch, R.M; dan van den Akker, $\mathrm{J}$ (eds). Design Approaches and Tools in Education and Training. London: Kluwer Academic Publisher.

A. King, D. 2005. Islamic Mathematical Astronomy. Variorum

London, tt.

Reprints.

Amalia, E., Surya, E., Syahputra, E. 2017. The Effectiveness Of Using Problem Based Learning (PBL) In Mathematics Problem Solving Ability For Junior High School Students. International Journal of Advance Research and Innovative Ideas in Education. Vol. 3. Issue-2.

Amri, S. 2013. Pengembangan \& Model Pembelajaran dalam Kurikulum 2013. Jakarta: PT. Prestasi Pustaka.

Arends, R. I. 2008. Learning to Teach Belajar untuk Mengajar Buku Dua (diterjemahkan oleh Soedjipto, P. Dan Soedjipto, Sri, M.) Yogyakarta : Pustaka Belajar.

Arends, R. I. 2009. Learning to Teach. Eight Edition. Americas, Newe York : Mc. Graw Hill.

Arikunto, S. 2006. Dasar-Dasar Evaluasi Pendidikan (edusu Revisi), Jakarta : PT. Bumi Aksara.

Arikunto, S. 2013. Prosedur Penelitian Suatu Pendekatan Praktek, Jakarta : PT. Rineka Cipta.
Arsyad, A. 2013. Media pembelajaran . Jakarta : Raja Grafindo Persada.

Ashyar, R. 2012. Kreatif Mengembangkan Media Pembelajaran. Jakarta : Gaung Persada (GP) Press Jakarta.

Balım, A. G. 2009. The Effects of Discovery Learning on Students' Success and Inquiry Learning Skills. Eurasian Journal of Educational Research, 35, 1-20.

Bandura, A. 1997. Self-Efficacy: Toward a Unifying Theory of Behavioral Change. Psycological Review. Vol. 84 No. 2, 191-215

Bandura, A. 2006. Guide for Constructing Self-Efficacy Scales. Information Age Publishing.

Bandura, A. 2009. Self-efficacy in changing societies. Cambridge, UK: Cambridge University Press.

Banjarnahor, S., Sinaga, B., Napitupulu, E. 2017. Analysis of Problem Solving Ability in Applying Problem Based Learning Reviewed From the Learning Style. Journal of Education and Practice. Vol.8. No 34. 127135.

Brown, J, W., Lewis R. B \& Harcleroad, F. F. 1983. AV Instructional: Technology, Media, and Method. New York: Mc. Graw-Hill Book Company.

Butar-Butar, A.J.R. 2016. Khazanah Astronomi Islam Abad Pertengahan. Purwokerto : UMP Press.

Campione, J.C. Brow, A.L, \& Connell, M.L.1988. Metakognition: on the Importance of Understanding What You Are Doing. In Charles, R.I, \&Silver, E.A. (Eds). The Teaching and Assessing of Mathematical Problem Solving. Vol.3. Reston, VA:NCTM.

Darren, R. S. 1994. Quadrant Construction and Aplication in Western Europe During the Early Renaissance. Kanada: National Library

Daryanto. 2014. Pendekatan Pembelajaran Saintifik Kurikulum 2013. Yoyakarta: Penerbit Gava Media.

Depdiknas. 2003. Media Pembelajaran. Jakarta: Depdiknas.

Depdiknas. 2008. Panduan Pengembangan Bahan Ajar. Direktorat Pembinaan Sekolah Menengah Atas.

Dewi, P. \& Ni, W, D. 2014. Pengembangan Perangkat Pembelajaran Matematika Dengan Pendekatan Scientific Berorientasi Teknologi Informasi Dan Komunikasi Untuk Meningkatkan Kemampuan Pemecahan Masalah Dan Penalaran Siswa. EJournal Universitas Pendidikan Ganesha.Vol.3.

Dominowski, R.L. 2002. Teaching Undergraduates. New Jersey: Lawrence Erlbaum Assosiates Publishers.

Eggen, Paul D \& Kauchak. (1979). Strategis for teachers teaching content and thinking skills. New Jersey: prentice Hall.

Elvina, A. 2012. Hubungan Antara Self Regulated Learning Dengan Kemampuan Memecahkan Masalah Pada Pembelajaran Matematika Pada Siswa SMUN 53 Di Jakarta Timur. (online). publication.gunadarma.ac.id

Faizi, M. 2012. Ragam Metode Mengajarkan Eksakta pada Murid Jogjakarta: Diva Press.

Forgarty, R. 1997. Problem Based Learning and Other Curriculum Models for the Multiple Intelligenes Classroom. Arlington Heights, Illinois; Sky Light.

Foshay, R., \& Kirkley, J. 2003. Principles for Teaching Problem Solving. ---- : Plato Learning. 
Hake, R. 1999. Analyzing Change/Gain Scores. Woodland Hills: Dept. of Physcis, Indiana University.

Hasratuddin. 2015. Mengapa Harus Belajar Matematika. Medan: Perdana Publishing.

Hidayat, M. 2017. Peningkatan Kemampuan Belajar Matematika dengan Menggunakan Media Rubu' $\mathrm{Al}$ Mujayyab. AL-MARSHAD. Vol. 3. No.2

Lili, YM, Gani T.\& Salempa P. 2017.Pengembangan Perangkat Pembelajaran Berbasis Proyek pada Praktikum Analisis Titrimetri. Pendidikan Kimia pps UNM,2017, vol. 1, no. 1 (26-34)

Hudojo, H. 1998. Mengajar Belajar Matematika. Jakarta: Proyek pengembangan Lembaga Pendidikan Tenaga Kependidikan Dikjendikti.

Hudojo, H. 2005. Pengembangan Kurikulum dan Pembelajaran Matematika. Malang: UM Press.

Ibrahim, M. \& Nur, M. 2000. Pembelajaran Berdasarkan Masalah, Surabaya : UNESA University Press.

Kanginan, M. \& Terzalgi, Y. 2013. Matematika untuk SMA-MA/SMK Kelas X. Bandung : Srikandi Empat Widya Utama.

Kaplan, A. \& Oztruk, M. 2015. The Effect of Concept Cartoons to Academic Achievement in Instruction on the Topics of Divisibility. Mathematics Education, 10 (2), Page 67-76.

Kikkley, J. 2003. Principles for Teaching Problem Solving: Tecnical Paper \#4. Indiana University: Plato Learning.

Kemendikbud. 2013. Panduan Teknis Memahami Buku Siswa dan Buku Guru di Sekolah Dasar. Jakarta: Direktorat Jenderal Pendididkan Dasar dan Direktorat pembinaan sekolah dasar.

Kuzle, A. 2013. Patterns of Metacognitive Behavior During Mathematics Problem-Solving in a Dynamic Geometry Environment. International Electronic

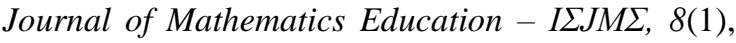
20-40.

Lestari, R. 2013. Pengembangan Media Pembelajaran Sel dengan Menggunakan Macromedia Flash untuk kelas XII SM. Jurnal Edu Research Vol. 3, No 2. Universitas Pasir Pangaraian.

Lestari, K.E., dan Yudhanegara, M.R. 2015. Penelitian Pendidikan Matematika. Bandung : Refika Aditama.

Lindegaard, T.K. 2014. The Siddhantasundara of Jnanaraja. An English Translation with Commentary. Maryland : Johns Hopkins University Press.

Liu, Min. 2005. Motivating Student Through ProblemBased Learning. University of Texas : Austin [online] Tersedia : http://[22-03-2007]

Manullang, M. \& Waminton, R. 2016. Some Factors That the Perfomance of Mathematics Teachers in Junior High School in Medan. Internasional Education Studies. (Online). Vol. 9, No. 4; 2016 (https://dx.doi.org/10.5539/ies.v9n4p165, diakses 20 November 2017).

Mareesh K, R.D., Padmavathy. 2013. Effectiveness of Problem Based Learning in Mathematics Vol. II Issue-I Januari Page 45,International Multidisciplinary e-Journal, www.shreeprakashan.com.

Maria, A. 2007. The Method of Problem Solving Based on the Japanese and Poly's Models. A Classroom Experience in Chilean Schools. Mathematics Department Basic Sciences Institute, Catholic University of Talca-Chili.

Marlina, M., Ikhsan. \& Yusrizal. 2014. Peningkatan Kemampuan Komunikasi dan Self-Efficacy Siswa SMP dengan Menggunakan Pendekatan Diskursif. Jurnal Didaktik Matematika. Vol.1, No.1. Page 35-45.

Masrinawati, A. 2003. Peranan Matematika dalam Era Globalisasi. Jakarta: Gramedia Pustaka.

Masjaya, \& Wardono. 2018. Pentingnya Kemampuan Literasi Matematika Untuk Menumbuhkan Kemampuan Koneksi Matematika Dalam Memeningkatkan SDM. PRIMA (Prosiding Seminar Nasional Matematika). (Online). (https://journsl.unnes.ac.id/sju/index/prisma/, diakses 20 Januari 2018).

Minarni, A. \& Napitupulu, E. E. 2017. Developing Instruction Materials Based on Joyful PBL to Improve Students Mathematical Representation Ability. International Education Studies. Vol. 10, No. 9. Page 23-38.

Minarni, A. 2012. Pengaruh Pembelajaran Berbasis Masalah Terhadap Kemampuan Pemecahan Masalah Matematis. (Prosiding Seminar Nasional Matematika dan Pendidikan Matematika 2012). (Online). (http://eprints.uny.ac.id/id/eprint/7496, diakses $28 \mathrm{Juli}$ 2018)

Moma, La. 2014. Peningkatan Self Efficacy Matematis Siswa SMP Melalui Pembelajaran Generatif. Fakultas Keguruan dan Ilmu Pengetahuan Universitas Pattimura. 